UDK: 7.01-055.2

Pregledni članak

Primljen 12. VI. 2018.

DORJA BOgOVIĆ

Rijeka

dorjabogovic@yahoo.com

\title{
CVIJEĆE - SIMBOLI ŽENSKE SEKSUALNOSTI U UMJETNOSTI
}

\section{Sažetak}

Između cvjetova i seksualnosti već dugo postoji jaka veza. Cvijeće predstavlja složene simbole i nije uvijek imalo pohotljivo značenje; ljiljan je, na primjer, povezan s likom Djevice Marije. Stroži su i rezerviraniji simboli $\mathrm{u}$ istočnoazijskim i islamskim dekorativnim umjetnostima ili $\mathrm{u}$ Nizozemskoj gdje su tulipani imali višu cijenu i vrijednost od slika. Istraživanje ovoga članka prikazat će na raznim primjerima bogatu povijest korištenja cvijeća i njegova simboličkog značenja vezana za žensku seksualnost. Cilj je ovoga rada prikazati kako je ta simbolika postojala još od drevnih vremena i kako se prožimala kroz povijest sve do danas.

Ključne riječi: simboli; umjetnost; cvijeće; žena; seksualnost

\section{Uvod}

Simbolika cvijeća puna je značenja, posebice ženskih i seksualnih asocijacija, te je snažno uklopljena u njihovu povijest. U Japanu se prakticira Hanakotoba koja se odnosi na drevnu umjetnost dodjeljivanja značenja cvijeću. U japanskoj kulturi poklanjanje cvijeća nije ograničeno na žene i ne radi se olako. Drugo, tajno značenje cvijeta određuje poruku poslanu primatelju te omogućuje prijenos osjećaja i emocija bez riječi. Pokazivanje ljubavi i zahvalnosti prema drugima s cvijećem 
jedan je od najčešćih razloga zbog kojih se ono i šalje. Isto tako, mogu se razlikovati različite vrste ljubavi ovisno o cvijeću koje se odabere. U prakticiranju Hanakotobe biljke su dobile vlastite šifre i lozinke. Tako, na primjer, bijeli ljiljan simbolizira čistoću ili nevinost, kaktus požudu, a gardenija slomljenu ili tajnu ljubav.

Floristička terminologija koja nosi cvjetni simbolizam često koristi paralelni analogni odnos između cvjetova ili njihovih dijelova i aspekata ženske spolne anatomije kao što su prsa, maternica i stidne usne, a također imenuje i faze ženskih seksualnih i reproduktivnih aktivnosti te seksualnih statusa i činova. Ako dalje analiziramo ovaj simbolizam, čovječanstvo se rađa iz utrobe žene, što znači da su seksualni i reproduktivni organi žene bit ili cvijet čovječanstva. Pubertet, ženski fiziološki procesi koji se događaju u tijelu, prvo seksualno iskustvo, plodnost, trudnoća i majčinstvo koncipirani su kroz florističke pojmove: zatvoreni pupoljci, zreli cvjetovi. Bez sumnje ta se povezanost dogodila zahvaljujući estetskim sličnostima sa ženskim genitalijama. Leksem cvjetanje u nekim se jezicima koristi za opisivanje određena razdoblja za ženu - u izrazu menstrualnoga cvjetanja.

\section{Cvijeće kao simbologija ženstvenosti u drevnim civilizacijama}

Cvijeće je oduvijek predstavljalo žensku seksualnost u gotovo svim dijelovima svijeta i na svim jezicima, osim u Africi gdje zbog klime jednostavno ne može preživjeti. Tu su važniji elementi lišće, kora i korijen stabala (usp. Goody, 1993: 12-14). Cvijet se koristi i kao negativan i kao pozitivan simbol te može prikazivati kako odsutnost tako i prisutnost seksualnosti. Isto tako, asocijacija žene s cvijetom izaziva viziju bespomoćna lijepa stvorenja kojemu je potrebna zaštita.

Primjer negativne simbologije onaj je gdje cvijeće, najčešće ruža, bijeli ljiljan ili zatvoreni vrt, simbolizira nedostatak seksualnosti kod žene, ali i nevinost, djevičanstvo i/ili čednost. Pozitivna korištenja ovih simbola nalazimo u paralelama između određenih vrsta cvijeća i aspekata 
ženske anatomije kao što su stidnica, vagina i rodnica koje koriste cvijeće kao prikaz i slavlje seksualnih činova ili sklonosti.

\subsection{Egipat}

Već u starome Egiptu cvjetovi su služili kao pozitivni i negativni simboli. Lotos se smatrao svetim cvijetom koji ima moć davanja novoga života. Iako mitovi ne govore direktno o ženskoj seksualnosti, povezuju ga s maternicom, ženskim spolnim organom. Naime, prema mitologiji, bog sunca Ra prije rođenja svijeta bio je zarobljen u lotosovu pupoljku iz kojega je zatim izašao te dobio ime Boga koji se uzdiže iz velikoga cvijeta lotosa. Isto tako, Knjiga mrtvih opisuje proces u kojem se pokojnik nakon smrti ponovno rađa iz lotosa, a drevni svećenici koristili su plavi lotos kako bi postigli stanje transa kao dio pogrebnoga obreda. Ova je ideja povezana s kultom sunca boga Ra i simbolikom lotosa kao rodnice iz koje je proizašlo čovječanstvo (usp. Goody, 1993: 39). Nasuprot tomu, drevni Egipćani koristili su ružu kako bi naznačili čednost, djevičanstvo i ljubav koja je slobodna od svih tjelesnih asocijacija u ritualima božice Isis.

\subsection{Grčka i Rim - štovanje božice cvijeća}

Čak su civilizacije drevne Grčke i Rima koristile slične simbolike. Božica ljubavi i zavođenja - Afrodita na grčkome, Venera na rimskome - simbolično se predstavljala cvijećem i drugim biljkama, uključujući ljiljanom, ružom, jabukom, šipkom, mirtom, dunjom, makom i mandragorom. Mirta je također vizualno povezana sa ženskim genitalijama, posebno vaginalnim usnama koje okružuju vaginalni otvor i čine dio stidnice podsjećajući Grke na samu biljku. Grčki liječnik iz prvoga stoljeća, Rufus iz Efeza, koristio je pojam mirtinih usana kako bi ukazao na labia majora, a plodom mirte označavao je labia minora.

Možda su još važniji od spajanja cvjetova sa seksualnošću rituali povezani s obožavanjem božice cvijeća - grčki Chloris, rimski Flora. U početku se vjerovalo da se Flora brinula za cvatnju žitarica, vinove loze i voćnih stabala, slična tako više božici žetve jer je cvijet povijesno 
simbolizirao obećanje cvjetanja; cvijet nije bio važan kao biljka sama po sebi. Tek kasnije Flora je postala božica cvijeća sa značenjem koje danas poznajemo. Od 240. do 173. godine Floralia ili cvjetne igre slavile su se svake godine u čast božice; festival je uključivao i ritualnu orgiju promiskuiteta.

Grci su među prvima identificirali neke cvjetne mirise sa seksualnošću nazivajući ih afrodizijacima. Ulje ljubičice bilo je jedno od tih afrodizijaka, a grčke žene premazivale su ga na svoja tijela prije seksualnoga čina. Rimljani su nastavili s ovim tradicijama i smatrali su da navodne moći cvjetova svetoga graha bude i potiču pozornost. Za teutonske narode grah je bio simbol seksualnoga užitka i erotizma i moguće je da su ga preuzeli odatle ili obratno.

U klasičnome razdoblju žene, posebice djevice, uspoređivale su se s cvjetovima kako u Virgilijevim poljoprivrednim Georgikama tako i u djelima pjesnikinje Sappho - koja u jednome fragmentu čini analogiju između žene, možda udane, i zumbula u planinama koje gaze pastiri. Na temelju simbolike cvijeća i voća u grčkoj arhaičnoj poeziji zumbul se u ovome fragmentu općenito tumači kao predstavljanje mladosti, ljepote i nevinosti. Neki smatraju da je fragment dio svadbene pjesme u kojoj Sappho ili zbor mladih žena tuguje radi predstojećega gubitka nevinosti nevjeste te neizbježna odlaska iz idealna svijeta strasti i mašte u svjetovnu stvarnost bračnoga života.

\section{Indija - dragulj u lotosu}

Indijska kultura, povijesna i suvremena, puna je primjera cvjetnoga simbolizma kao seksualnoga koda. Kako u Egiptu tako i ovdje postoji mitologija koja okružuje lotosov cvijet. Sanskritska riječ padma (lotos) vrlo se često koristi kao tajni kod za yoni, sanskritsku riječ za maternicu ili sveto mjesto (usp. Camphausen, 1991: 162). Sveti lotos postao je simbol plodnosti maternice, a njegov tučak simbol fetusa. Poput pupoljaka predstavljao je stidnicu djevojke koja je još djevica. Fraza dragulj u loto$s u$ na isti je način preuzela simbolično značenje; riječ dragulj simbol je za sjeme, muški spolni organ ili embrij, a riječ lotos simbolizira stidnicu 
ili maternicu. Ovaj izraz, dragulj u lotosu, postao je popularan kao dio meditacijske budističke mantre i još uvijek je štovan u suvremenome društvu među onima koji slijede Dalaj Lamu - iako mnogi suvremeni budisti negiraju eksplicitno seksualno značenje same fraze (usp. Edwardes, 1959: 75-76). Mjesečnica je još jedan aspekt ženskoga seksualnog iskustva koji je igrao važnu ulogu u simbolici cvjetova u Indiji. Istočnjački tekstovi prepoznaju barem šesnaest vrsta mjesečnica, a sve riječi završavaju pojmom puspa (sanskritski - cvijet), zajedničkim nazivom za crveni protok mjesečnice (usp. Camphausen, 1991: 126).

$\mathrm{Na}$ Andamandovim otocima, koji se nalaze u Bengalskome zaljevu, $\mathrm{u}$ nomadskim je plemenima još uvijek uobičajeno dati mladim djevojkama ime biljke ili stabla koje cvjeta u razdoblju u koje ulaze u pubertet. Kada djevojka dosegne pubertet, domoroci misle da je i ona cvjetala pod utjecajem istih prirodnih sila, stoga joj se daje naziv cvijeta koji se više neće koristiti nakon što rodi prvo dijete (Goody, 1993:18-19).

Naposljetku, cvjetovi predstavljaju seksualnost i senzualnost za oba spola u udvaranju i braku, osobito ako su vezani zajedno vijencima. U obliku braka poznata pod imenom Swayamvara vijenci se izmjenjuju između nevjeste i mladoženje (usp. Camphausen, 1991: 323).

\section{Europa - sklad pozitivnih i negativnih simbola}

U srednjovjekovnoj Europi cvijeće je često korišteno kao ukras u minijaturnim manuskriptima bez ikakvih seksualnih simbolika. Suprotna tome jest, primjerice, knjiga o duhovnim vizijama njemačke redovnice rođene 1098. godine, Hildegard von Bingen, pod imenom Scivias. Svaki opis vizija prate bogate dekoracije koje su prema njezinim instrukcijama iscrtale redovnice samostana Rupertsberg u Bingenu na Rajni. Vidjevši sliku velike žene, von Bingen piše:

Nakon toga vidjeh lik žene velike poput grada, sa prekrasnom krunom na glavi i rukama sa kojih je sjaj visio kao rukavi, sjajeći s Neba na Zemlju. Njezino krilo bilo je izbodeno poput mreže sa mnogo otvora, s mnoštvom ljudi koji su ulazil i iizlazili. Nije imala noge niti stopala, već je balansirano stajala na svom krilu pred oltarom koji stoji pred Božjim 
očima... Nisam mogla izvan njenog ruha, bila je ukrašena veličanstvenošću i sjala lucidnim mirom, a na njenim grudima sjao je crveni žar poput zore... I ta slika raširi svoj ukras tu poput halje, govoreći: „Moram začeti i dati porod!" (Flanagan, 1995: 70)

Iako je von Bingen ohrabrivala sestre i kršćanske svećenike da podrže svoje zavjete siromaštva, čestitosti i poslušnosti, slika stvorena da prati ovaj opis koristi pozitivnu simboliku cvjetnoga vrta kao ženske utrobe i majčinstva (usp. Hozeski, 1985: 220).

\subsection{Renesansa}

Europska renesansa vidjela je nastavak korištenja ovakva simbolizma u umjetnosti. Negativni simbolizam često je evociran na slikama Djevice Marije, dok se pozitivan simbolizam može naći u mnogim talijanskim slikama koje prikazuju figure iz grčke i rimske mitologije. Flamanski umjetnik Jan Brueghel stariji naslikao je zidani vrt kao simbol djevičanstva i Djevice Marije u svome djelu Madonna s djetetom $u$ vijencu cvijeća $i$ voća (početkom 17. stoljeća). U ovome dijelu cvjetovi koji krase rubove slike prolaze na desnu stranu gdje oblikuju vijenac koji okružuje Djevicu. Talijanski slikar Sandro Botticelli u svome djelu Proljeće (1477.) slavi ljepotu seksualnosti prikazanu u rimskoj božici Flori, nagoj i ukrašenoj vijencima cvijeća, izdahnjujući još i više cvijeća dok je lovi grčki bog vjetra. U Nizozemskoj je Rembrandt van Rijn također preuzeo asocijaciju božice Flore s ljubavlju i senzualnim užitcima prikazujući svoju ljubavnicu kao suvremenu Floru (1654.).

\subsection{Viktorijansko doba}

Korištenje cvijeća kao negativnih i pozitivnih simbola ostao je običaj sve do viktorijanskoga doba kada je prevladavao negativni simbolizam. Viktorijanski umjetnici željeli su promicati vrijednosti društva, a cvijeće je služilo kao simbol djevičanstva, seksualne nevinosti i povezivanje s generaliziranom ženstvenosti. Dva američka slikara ovoga razdoblja, Charles Courtney Curran i Robert Reid, vratit će ideju ograđena vrta 
(hortus conclusus) kao simbol seksualne čistoće koristeći se manipulacijom boja, strukture, kompozicije i oblika kako bi spojili svoje žene s cvjetovima i ogradama koje ih okružuju.

\section{Ograđeni vrt}

Koncept ograđena vrta služio je kao metafora i za žensko tijelo kao cjelinu i za ženski spolni organ. Vrt u kojem rastu mirisne biljke, voće, cvijeće ili drveće simbol je plodnosti, mjesta za uživanje. Štoviše, majčinstvo Djevice Marije sadrži, prema kršćanskim pjesnicima, u svojoj utrobi, predstavljenoj kao jedna kružna ruža, nebo i zemlju (Camphausen, 1991:155). Marija je često bila povezana s ružom, obično bijelom bez trnja, ali i s ljiljanom ili ljubičicom. U ritualima Djevice ruža označava čednost, djevičanstvo i ljubav koja je slobodna od svih tjelesnih asocijacija. Riječ vrt ima isto etimološko značenje kao riječ raj na perzijskome jeziku. Vrt je metafora seksualnoga raja te se kao takav spominje u Pjesmi nad Pjesmama, ciklusu ljubavnih pjesama Staroga zavjeta koje su u glavnome obliku sastavljene od dijaloga zaručnika i zaručnice:

Ti si vrt zatvoren, sestro moja, nevjesto, vrt zatvoren i zdenac zapečaćen. Mladice su tvoje vrt mogranja pun biranih plodova: nard i šafran, mirisna trska i cimet, sa svim stabljikama tamjanovim, smirna i aloj s najboljim mirisima. Zdenac je u mom vrtu, izvor žive vode koja teče $\mathrm{s}$ Libana. Ustani, sjevernjače, duni, južni vjetre, duni nad vrtom mojim, neka poteku njegovi mirisi. Neka dragi moj dođe u vrt svoj, neka jede najbolje plodove u njemu (Stari zavjet, 4: 12-16).

Zatvoreni vrt postaje simbol spolnoga integriteta, djevičanstva, nepropusnosti prema vanjskomu svijetu. Žensko tijelo percipira se kao zatvoren vrt. Riječi Ti si vrt zatvoren, sestro moja odnose se na tijelo zaručnice. U kasnijem stihu riječ vrt odnosi se ne samo na tijelo žene općenito već i na njezine genitalije. Tumačenje stihova jasno je: zaručnica metaforički uspoređuje svoj ženski spolni organ s vrtom. Neka jede najbolje plodove u njemu odnosi se na ljubavni čin.

Simbolizam cvjetnoga vrta također se može naći u kulturama Bliskoga istoka. Ovdje je ljiljan cvijet koji je često povezan s yoni. Ljiljan je 
važan simbol seksualnosti koji obuhvaća veliko područje i kulture Bliskoga istoka i Mediterana, čak i ako je ambivalentniji od lotosa. Osim yoni, ljubavi i strasti, može imati i druga značenja, poput djevice. Tako će se ljiljan u kršćanskim kulturama poslije koristiti kao simbol Djevice Marije. Općenitije, islamski cvjetni vrtovi predstavljaju središta ne samo molitve i meditacije nego i veselja i seksualnosti. Neki dvorski vrtovi izgrađeni su izričito u svrhu ljubavi i zapravo mnoge islamske slike prikazuju seksualne odnose koji se održavaju na cvjetnome tepihu u predivnu vrtu (usp. Goody, 1993: 109-110).

Na kraju, Mirisni vrt bio je arapski erotski priručnik, usporediv s indijskom Kama Sutrom. Premda slike cvijeća i vrta nisu bile ograničene na seksualne simbole, često su evocirane kao takve. Kako se kršćanstvo širilo u ranome srednjem vijeku, cvjetni simbolizam i obredi bili su izbrisani na Zapadu. Katoličke vođe zabranile su ih jer su se bojali bilo kakvih upućivanja na poganske religije. Na kraju, ipak, cvjetni simbolizam integriran je i u kršćanstvo, osobito povezan, kao što smo već rekli, s likom Djevice Marije.

\section{5. Ženska vizija u dvadesetome stoljeću}

Uključivanje seksualnoga cvjetnog simbolizma u dvadesetome stoljeće ne sastoji se od jednostavna praćenja tradicija. Prvi put u povijesti mnoge žene konačno su se mogle zaposliti u umjetničkoj karijeri te tako promijeniti umjetnička djela na temu ženske seksualnosti. Mnoge žene, osobito u prvoj polovici dvadesetoga stoljeća, metaforički su prenijele žensku seksualnost, a ne doslovno, jer je seksualnost još uvijek bila neprihvatljiva da se izričito raspravlja ili ilustrira. Budući da je jedno od rijetkih predmeta, koje su žene mogle slikati prije dvadesetoga stoljeća, bilo upravo cvijeće te uzevši u obzir dugu povijest korištenja cvijeća kao seksualnih simbola, neke su se umjetnice logično odlučile koristiti cvjetnim slikama s jasnim seksualnim konotacijama. Štoviše, freudovska teorija prema kojoj se seksualni simbolizam odnosio na mnoge svakodnevne stvari, osobito na cvijeće, plodove i različite artefakte, došla je „u modu“ u Europu 1910. i u SAD 1920. godine. To je olakšalo korištenje 
pozitivna seksualnog simbolizma, a Zapad je postao otvoreniji u prikazivanju i slavljenju same seksualnosti.

Anaïs Nin jedna je od prvih umjetnica koja je istraživala erotiku te otvoreno pisala o njoj. Njezina erotska knjiga Venerina Delta, objavljena početkom sedamdesetih godina 20. stoljeća, sadrži sljedeći opis:

Jedan od njih govorio je o ženi slikarici koja je ispunjavala galerije s divovskim cvjetovima u duginim bojama. „Ne radi se o cvijeću“, reče pušač lule, „Stidnice su. Svatko to može vidjeti. To je njena opsesija. Ona slika stidnice veličine odrasle žene. Isprva izgleda kao latice, srce cvijeta, onda se vide dvije neujednačene usne, tanku središnju liniju, valoviti rub usana, kada su otvoreni. Kakva ona žena može biti, kada uvijek pokazuje ovu divovsku stidnicu, koja sugestivno nestaje u tunelu ponavljanja, rastući od velike do manje, njena sjena, kao da se zapravo ulazi u nju. Osjećate se kao da stojite pred onim morskim biljkama koje se otvaraju samo da usisaju hranu koju mogu uhvatiti, otvorene istim valovitim rubovima" (Nin, 2004: 174).

\subsection{Utjecaji teorije psihoanalize}

Širenjem freudovskih inovativnih ideja na popularnosti su dobila umjetnička djela koja su se suočila sa seksualnošću u metaforičkome smislu, a kritičari su počeli tražiti skrivena psihoanalitička značenja u djelima raznih umjetnika, bez obzira na njihovu istinsku namjeru. Tako su slike cvjetnih oblika u prvome planu američke umjetnice Georgie O'Keeffe interpretirane isključivo kao seksualne metafore, unatoč neprekidnoj negaciji same umjetnice. Poput drugih ženskih umjetnika,O'Keeffe je morala suočiti svoj umjetnički identitet s identitetom žene. Mnogi smatraju da je ta freudovska tumačenja potaknuo Alfred Stieglitz, suprug umjetnice, kao metodu bolje promocije njezinih slika.

Iako su kritičari umjetnosti ustrajavali na tome da su baršunasta tekstura, raskošna boja i organski oblici njezinih slika bili usmjereni na seksualnost, O'Keeffe je odgovarala da želi slikati samo ono što vidi, povećavajući slike do nevjerojatnosti i prisiljavajući uvijek zauzete stanovnike New Yorka da se zaustave i odvoje vrijeme da ih pogledaju: „U dvadesetim godinama, govorila je, činilo se da u New Yorku ogromne 
zgrade samo niču niotkud iz dana u dan. Tako sam mislila napraviti da i cvijeće niče kao i te ogromne zgrade. Ljudi će se preplašiti, ali će ih morati gledati - i tako je i bilo."

Međutim, pri kraju svoga života O’Keeffe je priznala da su osjećaji intimnosti i seksualnosti mogli nesvjesno ući u njezina djela, da su se mogli jednostavno usaditi u njezin um u to doba opsjednutosti Freudovom filozofijom. Freudov suradnik, psihoanalitičar Carl Jung, 1961. izjavio je da se drveće i biljke često pojavljuju u snovima te da imaju mnoštvo značenja (usp. Jung, 1968: 79), a posebno je zanimljiva njegova teorija arhetipova. Jung je arhetipove shvaćao kao univerzalne, arhaične obrasce i predodžbe koje proizlaze iz kolektivnoga nesvjesnog i koje su psihološki suprotne instinktu te dobivaju izražaj pomoću individualaca i različitih kultura (usp. Stevens, 2006: 3).

Radi se o naslijeđenim potencijalima koji se aktualiziraju onda kada uđu u svijest poput slika ili se manifestiraju u ponašanju i interakciji s vanjskim svijetom (usp. Feist, 2009: 34). Postojanje arhetipova može se zaključiti samo indirektno pomoću priča, umjetnosti, mitova, religija ili snova. U teoriji Jungovi arhetipovi odnose se na nejasne temeljne oblike iz kojih se pojavljuju slike i motivi poput majke, djeteta i prevaranta. Povijest, kultura i osobni kontekst oblikuju te manifestacije dajući im svoj specifični sadržaj. Jung ističe kako se, primjerice, majčinski arhetip može pripojiti različitim prikazivanjima posuda poput krstionice ili cvjetovima poput ruže. Arhetip božanske majke povezan je sa skrivenim. Ona predstavlja mističnu spoznaju, a ruža je njezin simbol (usp. Jung, 1934: 157).

Američka slikarica Audrey Flack u svoje je radove zajedno ugradila cvjetnu simboliku i teoriju arhetipova. Njezina Marilyn (Vanitas) slika iz 1977. prikazuje Marilyn Monroe okruženu predmetima kao što su šminka, voće, nizovi perlica i ružičasti cvijet. Flack je mnogo razmišljala o pozicijama i bojama svakoga predmeta na slici. Priznala je da je prvobitno naslikala bijelu ružu nakon čega se odlučila za ružičastu boju koju je smatrala otvorenijom i delikatnijom (usp. Hauser, 2001: 26). Flack će kasnije izjaviti kako vjeruje u univerzalne simbole, odnosno jungovske arhetipove. Svatko će, kaže umjetnica, razumjeti simboličnu razliku 
između crne i bijele ruže, ruže koja je otvorena i puna ili je zatvoren pupoljak. Također, ružičasti cvijet pozitivan je simbol Marilynine otvorene seksualnosti; da je Flack zadržala bijelu ružu, bila bi protumačena kao negativni simbol seksualne nevinosti i čistoće. Ove su interpretacije poduprete poviješću, kao što smo vidjeli, i može se jasno raditi o jungovskim arhetipovima. Interpretacija je to koju je poželjela i sama umjetnica.

\subsection{Frida Kahlo - cvijeće kao simbol borbe za slobodu}

Meksička slikarica Frida Kahlo koristila je seksualni simbolizam cvijeća u svojim slikama. Iako je najpoznatija po svojim autoportretima, Kahlo je također slikala mrtve prirode, od kojih neke uključuju cvjetove ili voće koji se mogu shvatiti kao jasne seksualne metafore.

Godine 1938. Kahlo stvara Xochitl, malu, ali moćnu sliku cvijeta sastavljenu od dva suprotna, ali dobro integrirana dijela koji predstavljaju ženske i muške spolne organe. Sunce koje daje život obasjava falus i fetus koji se pojavljuje iz majčine utrobe (usp. Kettenmann, 2007: 32). Naslov se može prevesti kao cvijet ili nešto dragocjeno, delikatno s nahuatla, tradicionalnoga jezika Azteka. Štoviše, prema aztečkoj mitologiji cvjetovi su stvoreni od genitalija Xochitl, božice ljubavi. Inspiracija za sliku došla joj je od jednoga glifa koji prikazuje crveni cvijet koji je kroz gornji dio penetriran od strane trske te koji se može naći u Codexu Mendoza. Ovaj aztečki kodeks nastao je dvadesetak godina nakon španjolskoga osvajanja Meksika i sadrži povijest Azteka i njihovih postignuća kao i opise aztečkoga svakodnevnog života i tradicije.

Slike Fride Kahlo jasno povezuju cvjetne likove sa seksualnim konotacijama, a za razliku od O'Keeffe i ostalih, Kahlo svjesno želi ovo čitanje u njezinim djelima. Njezin rad Cvijet života iz 1944. godine još je jedan primjer korištenja cvijeća kao metafore za seksualnost. Ovdje se Kahlo igra vizualnim sličnostima između cvjetova i ženske seksualne anatomije slikajući cvijeće koje zauzima mjesto ženskih reproduktivnih spolnih organa. Većina njezinih djela su osobna i reflektirajuća, tako ni Cvijet života nije iznimka. Cvijet na kojem se ona sama projektira biljka 
je mandragore koja je postala poznata po liječenju neplodnosti još od Knjige Postanka. Vjeruje se da je mandragora sposobna pomoći u koncepciji i također učiniti sterilne žene plodnim.

Crvena mandragora raste na crvenim listovima koji simboliziraju ženske unutarnje spolne organe. Vagina i jajovod su prisutni, a nedostaju maternica i jajnici. Grom simbolizira penis koji ejakulira, a sunce odaziva orgazam. Ovdje Kahlo predstavlja cvijet kao genitalije žene, dostupne za zadovoljstvo muškarca, ali bez mogućnosti da sama osjeti ili zamisli užitak (usp. Grimberg, 2004: 27). U mnogim autoportretima aludira na vlastite komplikacije trudnoće s konkretnijim metaforama. Tumačenje mandragore u Cvijetu života, kao posebnim simbolom koji je vezan za seksualno iskustvo slikarice, time izgleda točno.

Na slici Bolnica Henryja Forda (1932.), koju je stvorila dok je bila u Detroitu sa suprugom i meksičkim slikarom Diego Riverom, Frida kombinira simboliku cvijeta s autoportretom. U ovome uznemirujućem djelu Kahlo leži gola u bolničkome krevetu nakon spontanoga pobačaja, okružena krvavim plahtama. Krevet lebdi u apstraktnome prostoru okružen sa šest predmeta i povezan arterolikim vrpcama, simbolima njezine seksualnosti i propale trudnoće (usp. Kettenmann, 2007: 32). $\mathrm{Na}$ dnu slike vidimo ljubičastu orhideju koja je izravno povezana s tijelom pomoću vrpce koja sugerira pupčanu vrpcu - kao i svih ostalih šest slika koje uključuju muški fetus, puža, anatomski model tijela koji pokazuje ženske spolne i reproduktivne organe, stroj koji najvjerojatnije pokazuje parni sterilizator i model kostura. Prema njezinim tvrdnjama, cvijet je donio sam Diego Rivera, a smatrala ga je simbolom seksualnosti i osjećaja. Nemogućnost umjetnice da rodi zdravo dijete vezana je za nesreću u autobusu koju je doživjela 1925. godine. Zbog toga se smatrala nepotpunom ženom, a osjećaj je ojačan stalnom nevjerom Diega Rivere.

\section{Mapplethorpe - cvijeće u centru društvenih promjena}

Drugi umjetnici iz 1960-ih i 1980-ih godina koristili su cvjetne slike kako bi privukli javnu pozornost na temu spola i feminizma. Naravno, postmoderna umjetnost koja se odnosi na seksualnost i cvjetne oblike 
ne može se promatrati bez spominjanja Roberta Mapplethorpea, poznata po tome što je zamaglio granicu između umjetnosti i pornografije. Njegove studije figura, cvijeća, portreta i fotorekonstrukcija istraživale su mušku ljepotu, homoseksualnost i sadomazohizam, a zanimljiva upotreba fotografskih rezova fetišizirala je i seksualizirala tijelo. Njegova Calla Lily (1988.) jasno pokazuje skriveni falus u obliku cvjetnoga tučka i stoga se može čitati slično njegovim fotografijama penisa u erekciji (usp. Schor, 1997: 28).

Njegove eksplicitne slike zapravo čine samo mali dio rada, a nadmašuju ih portreti, studije bodybuilderice Lise Lyon i osobito strogo sastavljene slike cvijeća. Kale, tulipani, afričke tratinčice: one, jednako kao i njegovi muškarci odjeveni u kožu in flagrante delicto, pravi su subjekti Mapplethorpeove umjetnosti, sredstva kroz koje je oblik postao ljepota.

Kada gledamo njegove fotografije cvijeća, zaboravljamo na klasičan prikaz devetnaestoga stoljeća, Maneteove bukete ili Renoirove vaze krizantema, jer ih zamjenjuje duboka i nemilosrdna analiza anatomije pojedinih cvjetova kao da se radi o seksualnim partnerima koji se moraju dirati, istražiti, uzbuditi. Njegove orhideje, kada se gledaju u neposrednoj blizini, s tajanstvenim laticama postaju zamjena za ženske genitalije. U prošlosti se često koristio jezik cvijeća kako bi se uvele diskretne poruke u ritualnim gestama dugoga udvaranja, ali kod Mapplethorpea suptilnosti nestaju i izazivaju maštovite slike sadomazohizma (Rosenblum, 2005).

Njegove početne fotografije cvijeća djeluju ograničene na njihov površinski sloj. Prve slike, kao što su Tiger Lily Buds (1977.) i Gardenia and Tulip (1978), pod utjecajem su svjetlosti koja ih osvjetljuje na zavodljiv, ali primitivan način. Svjetlo i pozadina koriste se kao alati intenziviranja boje i simetrije, čime se povećavaju kontrasti između crna i bijela, puna i prazna. Iako cvijeće obećava pristup punašnoj gustoći, ovo bogatstvo ne cilja na senzualnost predmeta. Međutim, od 1982. njegove orhideje i palmino lišće, tulipani i ruže uvijek su predstavljene s crno-bijelom pozadinom i vazom. Ovaj trend nastavljen je sve do 1986. godine u radovima kao što su Calla Lily, Iris i Leaf koji se stapaju s igrama sjena i 
kiparskih komada te monokromatskim pozadinama: naše oči izazvane su da se zaustave na senzualnosti i erotskoj ljepoti ovih cvjetova.

Krhka i otečena, zapravo su tijela kakva bismo mogli željeti, izgledaju gotovo kao zabranjeno meso. Ponuđeni su kao tjelesni predmeti i manifestacije duboke senzualnosti. Izgledaju možda čak i više uznemirujuće od sadomazohističkih fotografija jer pružaju beskrajno bogatstvo. Izgled rasta, gotovo uvijek uzrokovanim prirodnim svjetlom, stvara gestu uzdizanja i erekcije: seksualnoga i duhovnoga stvaranja, muškoga i ženskoga, faličkoga i klitorisnoga. „Dobivam nešto od cvijeća što drugi ne mogu razumjeti. Potpuno uronim u taj cvijet. Volim fotografije cvijeća više od pravoga", tvrdi Mapplethorpe (usp. Gerrit, 1982: 129).

\section{Zaključak}

Istraživanje ovoga članka prikazalo je raznim i mnogobrojnim primjerima bogatu povijest korištenja cvijeća i njegova simbolična značenja vezana za žensku seksualnost. Cilj ovoga rada postignut je prikazom simbolike koja je postojala još od drevnih vremena te se prožimala kroz povijest sve do danas.

Naravno, današnji umjetnici još uvijek koriste cvijet kao metaforu seksualnosti - vrlo često ženske seksualnosti. Međutim, potreba za takvim simbolizmom u umjetnosti smanjila se. Negativan seksualni simbolizam, toliko popularan u renesansnoj i viktorijanskoj eri, gotovo je izumro. Čak je i pozitivan seksualni simbolizam manje zastupan nego što je bio u prošlosti. Lako je pronaći velik broj umjetnika koji uključuju seksualne teme u svoje radove, ali nije lako pronaći nekoga tko to radi koristeći simboliku cvijeća.

Dok su umjetnice iz prošlosti morale koristiti simboliku u prikazivanju seksualnosti, današnje društvo otvoreno govori o toj temi, čak i u najizrazitijim oblicima. Veliku važnost u toj slobodi ima pokret feminističke umjetnosti početkom 1970-ih koja se podudara sa seksualnom revolucijom. To nije bila slučajnost. Ženska se savjest probudila i zahvatila je sve žene na svjesnoj i nesvjesnoj razini. Umjetnici su po prirodi promatrači, a umjetnice iz toga vremena nisu samo osjećale učinke 
seksualne revolucije, već su i reagirale na nju. Žene su se počele izražavati i dokazivati kao fizička, seksualna bića. Umjetnost žena u tome razdoblju počela je koristiti simboliku koju su u prošlosti koristili samo muškarci, počevši slikati nage muškarce, ali i prikazivati seksualno eksplicitne radnje.

Poststrukturalističke teoretičarke u tome razdoblju, poput Julije Kristeve, propituju sve oblike formalizma i strukturalizma koji se zasnivaju na razumu i racionalnosti te koji su sami po sebi muški. Ona službeno narušava racionalni (muški) jezik suprotstavljajući mu pojam (ženske) poetičnosti. Poput mnogih žena njezine generacije i Kristeva prihvaća ideje Sigmunda Freuda i Jacquesa Lacana, ali ih i kritizira bez namjere da odbaci njihove ideje i teorije. U djelima Sigmunda Freuda žena je tamni kontinent, za Jacquesa Lacana ona ne postoji, a namjera Kristeve jest da obnovi davno izgubljeno tijelo majke i da vrati pojam ženskoga u jeziku (usp. Kristeva, 2011: 54).

Istaknuta francuska filozofkinja Luce Irigaray zagovara emancipacijsku i radikalno transgresivnu definiciju ženske seksualnosti koja oslobađa koncept istoga od falocentrična diskursa o ženstvenosti. Irigaray inzistira na razvoju prepoznatljive ženske seksualnosti koja naglašava njezinu raznolikost te priznaje diskriminaciju iste u zapadnoj kulturi koja je pod snažnim utjecajem Freudovih misli. Piše kako je Freudovo izvješće ženske seksualnosti karakterizirano samo kroz upućivanje na mušku seksualnost, kao norma za sve ljude. Irigaray ističe kako je ženska seksualnost zapravo oduvijek koncipirana na temelju muških parametara (usp. Irigaray, 1991: 353).

Teoretičarka Hélène Cixousu u svome čuvenom eseju Smijeh Medu$z e$ tvrdi kako su muškarci prisilili žene da se udalje se od umjetničkoga stvaranja, vlastitih tijela i seksualnih želja. Muškarci su ispisivali povijest, provodili zakone, posvećivali se medicini i znanosti te pisali i objavljivali radove, a javne prostore koristili su kako bi definirali žene kao manje vrijedne. Kao žena koja piše, ona od drugih žena traži da učine isto, da ne dopuste da ih itko i išta zaustavi ili zadrži od pisanja svojih životnih priča. Činovi umjetničkoga stvaranja za žene i koje stvaraju žene nužni su jer do sada nije bilo takvih koji bi otvoreno govorili o ženstvenosti. 
Njima ne samo da prisiljavaju muškarce da promisle o svojem stavu o ženama već i traže od njih da ih uzdignu na višu razinu. Ženska je imaginarnost neiscrpna poput glazbe, slikanja i pisanja. Njihov je tok fantazija nevjerojatan, a ako bi ga žene ugasile, uništile bi svoje društveno i političko ugnjetavanje koje ih je stoljećima ograničavalo. Jedini način na koji žene mogu dobiti pristup svojoj izvornoj snazi i promijeniti ili napisati novu povijest jest da se same upišu u istu. „Pišite same. Vaše se tijelo mora čuti“" (Cixous, 1976: 875).

Suvremena povezanost cvijeta i seksualnosti lako je prepoznatljiva u popularnoj kulturi širom svijeta. Cvjetovi su još uvijek prisutni u zapadnim društvima kao dio udvaranja i rituala koji se odnose na seksualnost. Slanje cvijeća nakon spoja možda je vidljiv pokazatelj postignute intimnosti ili intimnosti koja je žarko poželjna (usp. Goody, 1993: 295). U Španjolskoj plesači flamenca nose haljine koje podsjećaju na latice karanfila, cvijeće koje je, prema mnogim običajima i ritualima, iberijski ekvivalent ruže. Tijekom corride crveni se karanfili nose iza uha kako bi prikazali seksualnu dostupnost, a nakon uspješna završetka borbe karanfili se bacaju u arenu. Hinduistički hramovi još uvijek koriste drevni simbolizam yoni identificirajući cvijeće, trokute i dva ovalna vrha sa ženskim genitalijama.

Danas se, osobito u oglašavanju, često koriste cvjetne slike za zamjenu eksplicitnih spolnih organa ili da bi pobudile opći osjećaj senzualnosti i seksualnosti. Neke se kampanje posebno usredotočuju na razumijevanje veze između seksualnosti i cvijeća kako bi u potpunosti iskazale svoju poruku, kao što je kampanja za oglašavanje Amnesty Sweden koja koristi sliku ruže zatvorenu šavovima kako bi povećala svijest o nasilju nad ženama i ženskim genitalijama.

\section{Literatura}

- Bencard, Jonas - Holm, Michael - Tojner, Poul Eric (2004) The Flower as Image, Lousiana Museum of Modern Art, Copenhagen 
- Biblija (2016) „Pjesma nad Pjesmama“, Stari Zavjet, Verbum, Split.

- Biedermann, Hans (1992) Dictionary of Symbolism: Cultural Icons and the Meaning behind them, Facts on File, New York

- Camphausen, Rufus (1991) The Encyclopedia of Erotic Wisdom: A Reference Guide to the Symbolism, Techniques, Rituals, Sacred Texts, Psychology, Anatomy, and History of Sexuality, Inner Traditions International, Rochester, VT.

- Cixous, Hélène (1976) The Laugh of the Medusa, University of Chicago Press, Chicago.

- Edwardes, Allen (1959) The Jewel in the Lotus: A Historical Survey of the Sexual Content of the East, The Julian Press, New York.

- Ferber, Michael (1997) A Dictionary of Literary Symbols, Cambridge University Press, Cambridge.

- Ferguson, George (1954) Signs and Symbols in Christian Art, Oxford University Press, New York

- Flanagan, Sabina (1995) Hildegard von Bingen, a visionary Life, Routledge, London.

- Gerrit, Henry (1982) Robert Mapplethorpe - Collecting Quality, The Print Collectors Newsletter, New York.

- Goody, JACK (1993) The Culture of Flowers, Cambridge University Press, Cambridge.

- Grimberg, Salomon (2004) „Frida Kahlo’s Still Lifes: I Paint Flowers So They Will Not Die“, Woman's Art Journal, god. XXV, br. 2, str. 25-30.

- Hauser, Katherine (2001) „Audrey Flack's Still Lifes: Femmininity and Femminism“, Woman's Art Journal, god. XXII, br. 2, str. 26-30.

- Hozeski, Bruce (1985) Hildegard Von Bingen's Mystical Visions, Oxford University Press, Oxford. 
- Irigaray, Luce (1991) Female Desire, Blackwell Publishers, Oxford.

- Jung, Carl (1968) Man and his symbols, Dell Publishing, New York.

- JUng, Carl (1934) Archetypes and the collective Unconscious, Princeton University Press, Princeton.

- Kettenmann, Andrea (2002), Kahlo, Taschen, Köln.

- Kristeva, Julia (2011) „Some observations on Female Sexuality“, Routledge, New York, str. 41-53.

- Lynes, Barbara (2002) Georgia O'Keeffe and the Calla Lily in American Art, 1860 - 1940, Yale University Press, New Haven.

- MATTHEWS, BORIS (1991) The Herder Dictionary of Symbols: Symbols from Art, Archeology, Mithology, Literature and Religion, Chiron Publications, Asheville, NC.

- Nin, Anais (2004) Delta of Venus, Houghton Mifflin Harcourt, London.

- Papadopoulos, Renos K. (2006) The Handbook of Jungian Psychology, Routledge, London.

- Roberts, Helene (1998) Encyclopedia of comparative Iconography, Fitzroy Dearborn, London.

- Rosenblum, Robert (2005) „Robert Mapplethorpe: il punto di vista di uno storico dell'arte", MAPplethrope, Robert, Tra antico e moderno. Un' antologia A cura di Germano Celant, Artificio Skira srl, Firenza.

- Schor, Mira (1997) Wet - On Painting, Feminism and Art Culture, Duke University Press, Durham.

- Seward, Barbara (1960) The Symbolic Rose, Columbia University Press, New York.

- Whittick, Arnold (1960) Symbols, Signs and their Meanings, Leonard Hill, London 
Review article

Received June 12, 2018.

DorJa Bogović

\title{
FLOWERS - SYMBOLS OF FEMALE SEXUALITY IN THE ART
}

\begin{abstract}
For a long time there has been a strong link between flowers and sexuality. Flowers are complex symbols and they certainly did not always have salacious meanings; lilies, for example, are associated with the image of the Virgin Mary. There are stricter and more reserved symbols in East Asian and Islamic decorative arts, or in the Netherlands, where tulips had a higher price and value than paintings. The research of this paper will show the rich history of using flowers and its symbolic meaning related to female sexuality through many examples. The aim is to show how this symbolism has existed since ancient times and pervaded history all the way to our times.
\end{abstract}

Keywords: symbols; art; flowers; woman; sexuality 